\title{
GBA ADVERTISMENT : PENDEKATAN BERBASIS GENRE DALAM PEMBUATAN IKLAN PARIWISATA MAHASISWA VOKASI
}

\author{
Nyoman Ardiana Listriyawati \\ Program Studi Nautika, Universitas Hangtuah \\ e-mail:nyoman.ardiana@hangtuah.ac.id
}

\begin{abstract}
This study tried to applied the Application of Genre Based Approach to students to write advertisements in English class at Universitas Airlangga. This research was classified as qualitative by trying to find information related to lecturers who applied the Genre Based Approach for third semester students, modifications made by lecturers in the application of the Genre Based Approach, and the results of student work in responding to the implementation of the Genre Based Approach. This research included describe, recorded, and categorized with observation and interview techniques, where the description of data analysis is presented textually. The results showed that the lecturers have implemented all stages in the Genre-Based Approach with some modifications that are tailored to the needs of students, then all student works have fulfilled the purpose of an advertisement, namely to promote tourist attractions and attract readers to come and visit these places.
\end{abstract}

Keywords: Genre-Based approach; writing skills; student work

\begin{abstract}
ABSTRAK
Penelitian ini mencoba untuk menyelidiki penerapan Genre Based Approach pada mahasiswa pariwisata untuk menulis iklan di kelas bahasa Inggris di Fakultas Vokasi Universitas Airlangga. Penelitian ini tergolong kualitatif dengan mencoba mencari informasi terkait dosen yang menerapkan Genre Based Approach untuk mahasiswa semester tiga, modifikasi yang dilakukan dosen dalam penerapan Genre Based Approach, dan hasil kerja mahasiswa dalam menanggapi implementasi Genre Based Approach. Penelitian ini meliputi penggambaran, pencatatan, dan pengkategorian dengan teknik observasi dan wawancara, dimana uraian analisis data disajikan secara tekstual. Hasil menunjukkan bahwa dosen sudah mengimplementasikan semua tahapan dalam Genre Based Approach dengan beberapa modifikasi yang disesuaikan dengan kebutuhan mahasiswa kemudian seluruh hasil karya siswa sudah memenuhi tujuan dari sebuah iklan yaitu untuk mempromosikan tempat wisata dan menarik pembaca untuk datang dan mengunjungi tempat tersebut.
\end{abstract}

Kata kunci: pendekatan berbasis genre; keterampilan menulis; karya siswa

\section{PENDAHULUAN}

Bahasa Inggris bagi pelajar di Indonesia dipelajari sebagai bahasa asing. Bahasa ini belum menjadi bahasa komunikasi sehari-hari karena bahasa pertama adalah Bahasa Indonesia. Di Indonesia, bahasa Inggris diajarkan dari tingkat taman kanak-kanak sampai universitas karena saat ini bahasa Inggris

Cara mengutip: Listriyawati, N.,A. (2021). GBA Advertisment : Pendekatan Berbasis Genre dalam Pembuatan Iklan Pariwisata Mahasiswa Vokasi. Inteligensi: Jurnal Ilmu Pendidikan, 4(1), 57-66 
digunakan sebagai bahasa internasional untuk komunikasi sebagaimana dinyatakan oleh Baker dan Westrup (2012) bahwa di banyak negara, kursus menengah dan universitas diajarkan dengan menggunakan bahasa Inggris. Dengan pengajaran bahasa Inggris pada jenjang tersebut, diharapkan siswa Indonesia mampu menggunakan bahasa Inggris sebagai bahasa komunikasi. Untuk mencapai tujuan di atas melalui proses belajar mengajar di perguruan tinggi, ada dua hal utama yang harus diperhatikan, dosen dan pendekatan yang digunakan. Di sini dosen harus dapat menentukan pendekatan tertentu yang akan digunakan di dalam kelas karena dosen harus mengetahui dengan baik karakteristik siswa untuk memutuskan pendekatan yang paling cocok untuk memenuhi tujuan pembelajaran. Menurut Ary, et al (2010), guru yang telah mengetahui pendekatan yang mereka gunakan di kelas dengan baik akan menjadi lebih jelas tentang mengapa dan apa yang mereka lakukan. Dosen perlu mengetahui dengan baik kapan seorang pembelajar membutuhkan lebih banyak bimbingan dan lebih sedikit. Hal ini akan memberikan kesempatan kepada pembelajar untuk mengeksplorasi pengetahuannya sendiri.

Dalam rangka memberikan kesempatan kepada mahasiswa untuk menggali ilmu, dosen Fakultas Vokasi Universitas Airlangga ini mencoba menerapkan pendekatan tertentu karena sebagian besar mahasiswa mengalami kesulitan dalam memproduksi sebuah teks. Siswa terkadang tidak dapat menggunakan aturan tata bahasa yang sesuai atau mengorganisasikan konstruksi dengan benar berdasarkan masalah atau tujuan penulisan, koherensi, dan ide yang terbatas. Oleh karena itu, sebelum menghasilkan teks, mahasiswa harus memahami cara menyusun teks tulisan, dan dosen harus memilih pendekatan yang tepat untuk menyelesaikan masalah tersebut.

Merujuk pada pendekatan yang mungkin digunakan dalam proses belajar mengajar, banyak sekali pendekatan yang dapat digunakan dalam proses belajar mengajar. Namun, harus ada yang paling tepat untuk diterapkan di kelas tergantung pada kebutuhan pembelajar dan tujuan pembelajaran. Hal ini dikemukakan oleh Ary, et al (2010) bahwa "guru akan memiliki pemahaman untuk melakukannya jika mereka mampu dan mau". Dengan menggunakan pendekatan yang sesuai akan membantu untuk mengakomodasi kebutuhan peserta didik sehingga dosen akan menangani proses pembelajaran termasuk pengajaran dan interaksi di dalam kelas akan lebih mudah.

Salah satu pendekatan yang dianggap cocok untuk mahasiswa dalam menulis adalah Pendekatan Berbasis Genre. Pengajaran penulisan genrespesifik mungkin berharga karena menawarkan beberapa kasus kepada siswa yang memiliki presentasi terbatas pada penulisan bahasa Inggris yang sebenarnya. Pendekatan ini dapat membuat siswa menyadari tujuan yang berbeda dari teks tertulis karena difokuskan pada model teks dan fitur-fitur utama dengan gagasan murni tentang struktur dialek apa yang harus diucapkan dan bagaimana kepuasan harus direncanakan. Siswa harus memahami bahwa komunikasi terjadi dalam konteks sosial dan memiliki tujuan. Lebih lanjut Bhatia (2013) menyatakan bahwa pendekatan yang menekankan pada penciptaan makna pada tataran 
keseluruhan teks. Chayaningsih (2013) juga menyatakan bahwa metode ini mampu memberikan kesempatan yang luas kepada siswa untuk mengetahui perbedaan tujuan berita tertulis dan perbedaan metode sebagai suatu informasi yang disusun dalam teks tertulis. Dalam konteks ini, pendekatan genre sangat bermanfaat karena menyatukan sifat-sifat formal dan fungsional suatu bahasa dalam pengajaran menulis, dan mengakui bahwa ada asosiasi yang kuat di antara mereka. Selain itu, pendekatan genre dapat mendorong siswa untuk tertarik dengan ciptaan di sekitar mereka, untuk memahami menulis sebagai instrumen yang dapat mereka terapkan, dan untuk menyadari bagaimana penulis mengawasi substansi untuk memajukan organisasi yang konsisten.

Penggunaan pendekatan genre dalam pengajaran menulis yang sudah dipertimbangkan pada pertengahan tahun 1980-an sebagai garis besar untuk pengajaran bahasa menurut contoh kategori tertentu seperti yang dikemukakan oleh Cameron (2013) bahwa sistem pengurutan mendasari siswa menulis dengan umum, aturan mengarahkan tertib hampir bagaimana menyampaikan pesan penting. Ini memiliki pedoman yang meyakinkan yang biasanya terkait dengan ketekunan seorang penulis. Guru harus menyajikan berbagai genre untuk membuat siswa memahami dan melatih beragam lingkaran keterampilan dalam rencana pelajaran mereka. Melihat titik ini, Deng, et al (2014) menyatakan bahwa guru harus berpikir dalam hal kegiatan daripada pilihan metodologis ketika mereka merencanakan pelajaran mereka seperti dalam pendekatan ini dilaksanakan secara bertahap atau langkah. Guru harus mampu memajukan siswa pada setiap tahapan yang memiliki fungsinya dalam mewujudkan suatu tujuan tertentu. Tahapan ini dapat mengarahkan pembelajar untuk menghasilkan teks komunikatif karena pembelajar akan memiliki pengetahuan yang baik tentang organisasi dan fungsi teks. Dalam memproduksi teks, guru harus mengetahui bahan yang digunakan dalam pengajaran karena dapat mendorong siswa untuk mengeksplorasi pengetahuan mereka. Guru dapat menggunakan model atau memberikan contoh teks untuk mengilustrasikan ciri tertentu dari teks yang dipelajari seperti yang dikemukakan oleh Flemming (2011), contoh ilustratif wacana tanda dapat diperiksa, diasosiasikan, dan dioperasikan agar siswa sadar terhadap fakta bahwa menulis bervariasi jenis lintas dan bahwa mereka mungkin ingin menggambar pada konstruksi khusus dan fitur bahasa dengan sengaja untuk mencapai area penulisan mereka. Bentuk gramatikal juga penting untuk membantu agar makna yang ingin disampaikan kepada pembaca dapat diterima dengan baik. Guru memberikan informasi dan bimbingan yang cukup untuk merangsang siswa memproduksi teks secara efektif, meskipun hanya singkat.

Ada beberapa penelitian sebelumnya terkait GBA dan implementasinya. Penelitian pertama dilakukan oleh Wardhani (2012) di Surabaya. Dia fokus pada peran guru dalam menerapkan metode berbasis tipe dalam melatih huruf naratif kepada siswa kelas satu sekolah menengah atas. Dia menggambarkan cara mengajar di setiap tahap dalam Pendekatan Berbasis Genre. Hasil penelitian menunjukkan bahwa guru belum memberikan bimbingan yang optimal 
kepada siswa di semua tahapan. Hasil penelitian ini menunjukkan bahwa guru belum mengetahui dengan baik prosedur pelaksanaan GBA. Penelitian kedua dilakukan oleh Cahyaningsih (2013) di Surabaya. Dalam studinya, ia fokus pada kursus pembinaan dan pendidikan teks deskriptif dengan pendekatan berbasis genre dan kemampuan menulis siswa ketika siswa dilatih dan diajar dengan pendekatan berbasis genre. Penelitian ini juga menunjukkan bahwa guru tidak mengetahui prosedur GBA. Temuantemuan dari penelitian terdahulu tersebut mendorong dilakukannya penelitian ini, dimana untuk mencari bukti apakah pelaksanaan GBA di fakultas Vokasi Universitas Airlangga memenuhi prosedur GBA yang sesuai karena dosennya adalah mahasiswa magister yang diasumsikan mengetahui dengan baik prosedur GBA dan menerapkannya dengan tepat serta bagaimana hasil kerja siswa dalam memproduksi iklan setelah perlakuan menggunakan GBA.

\section{METODE PENELITIAN}

Penelitian ini direncanakan untuk mengetahui pengoperasian Genre Based Approach pada mahasiswa pariwisata di kelas Bahasa Inggris Fakultas Vokasi Universitas Airlangga Surabaya. Berdasarkan dua pertanyaan penelitian, penelitian ini menggunakan desain deskriptif kualitatif untuk mendapatkan informasi terkait penerapan pendekatan berbasis genre untuk mahasiswa. Sebagai penelitian kualitatif, peneliti akan memperoleh pandangan mendalam pada individu tertentu, katakanlah, atau situasi tertentu. Dalam penelitian ini, untuk mengumpulkan data dilakukan dengan melakukan observasi dan wawancara
(Creswell, 2012). Menurut Miles, et al (2014) data dalam penelitian kualitatif berupa argumentasi yang bersifat verbal berupa teks yang dilindungi. Ilmuwan kualitatif mulai menitikberatkan pada topik penelitian, koper yang harus dipertimbangkan, data yang akan disusun, dan bagaimana data tersebut akan dicapai dan dianalisis. Data penelitian terdiri dari lisan dan non lisan pendidik dan siswa melalui partisipan yang diamati dalam pekerjaannya yang akan menjadi database kualitatif. Perilaku verbal meliputi instruksi dosen, pertanyaan dan penjelasan serta komentar mahasiswa. Sedangkan perilaku nonverbal meliputi gerak tubuh dosen dan mahasiswa, gerak tubuh, tindakan dan aktivitas. Dengan setiap bentuk data, informasi dikumpulkan sebanyak mungkin untuk mengumpulkan laporan rinci untuk laporan penelitian akhir.

\section{HASIL DAN PEMBAHASAN}

Penelitian ini dilakukan untuk mengetahui implementasi Genre Based Approach dalam pengajaran menulis kepada mahasiswa pariwisata di kelas Bahasa Inggris Fakultas Vokasi Universitas Airlangga Surabaya yang difokuskan pada mahasiswa semester tiga. Dari hasil observasi dan wawancara diperoleh beberapa hal yang dapat menjawab pertanyaan terkait penerapan Genre Based Approach dan hasil kerja siswa dalam menanggapi penerapan Genre Based Approach. Pengamatan di kelas menemukan bahwa dosen telah menerapkan semua langkah dalam Genre Based Method kepada mahasiswa pariwisata untuk menghasilkan iklan tertulis. Di sini, dosen memberikan pengetahuan eksplisit awal dan praktik 
terbimbing, beralih ke berbagi tanggung jawab untuk mengembangkan teks, dan secara bertahap menarik dukungan sampai pembelajar dapat bekerja sendiri. Dosen berusaha menciptakan situasi yang atraktif dengan beberapa kegiatan dalam terstruktur data lapangan dan pemodelan fase teks. Kegiatan tersebut dapat mendorong siswa untuk mengungkapkan pendapat dan pengetahuan mereka tentang iklan sebelum mereka memproduksi sebuah iklan.

Kegiatan dalam membangun pengetahuan teks atau setting konteks dengan memberikan contoh bagaimana melakukan promosi verbal objek wisata dan membiarkan siswa melakukan hal yang sama agar mereka mengalami pengalaman melakukan promosi verbal. Kegiatan ini dilakukan untuk meningkatkan keterampilan berbicara mahasiswa untuk berkomunikasi karena kebutuhan dasar mahasiswa pariwisata adalah komunikasi yang baik dalam bahasa Inggris, baik lisan maupun tulisan. Hal ini diinformasikan oleh dosen bahwa peningkatan keterampilan komunikasi sangat penting bagi mahasiswa pariwisata. Para siswa perlu mengidentifikasi tujuantujuan utama seperti mendeskripsikan, menjelaskan, menganalisis, merekam, dan mengevaluasi dan kemudian memilih jenis-jenis yang relevan untuk dimuat dalam setiap tema yang akan membantu menumbuhkan makna-makna ini. Pilihan genre dikuatkan oleh sifat subjek atau tema unit karya. Di sini dosen mengetahui bagaimana meningkatkan kemampuan berbicara mahasiswa dengan memberikan kegiatan melakukan promosi verbal.

Setelah mahasiswa melakukan promosi verbal, dosen menjelaskan tentang sifat dari iklan tersebut. Hal ini terkait dengan fungsi dan fitur utama dari iklan. Dengan menginstruksikan mahasiswa untuk melakukan promosi verbal, dosen memberikan kesempatan kepada mahasiswa untuk menyebutkan apa yang mereka ketahui tentang iklan sebelum memberikan penjelasan. Hal ini dilakukan untuk merangsang siswa memiliki pengetahuan dari pengalaman mereka. Kegiatan pemberian contoh promosi verbal dan yang dilakukan siswa untuk melakukan promosi verbal adalah memberikan kesempatan kepada siswa untuk menggali pengetahuan tentang fungsi teks. Tahap ini penting karena dosen dan murid membantu membentuk informasi kolektif dari arena untuk menginspirasi siswa untuk memberitahu dan mendorong pemikiran mereka dan memungkinkan dosen untuk belajar setelah mereka.

Komunikasi antara dosen dan mahasiswa juga berjalan dengan baik karena pertanyaan dari dosen dijawab oleh mahasiswa secara aktif. Dengan memberikan umpan balik yang positif kepada siswa akan membuat proses belajar mengajar menjadi sukses. Dalam pemodelan teks, dosen memberikan contoh video iklan. Video tersebut tentang iklan gadget. Kegiatan tersebut dilakukan untuk memberikan gambaran kepada siswa tentang iklan yang baik dan fungsi promosi. Mahasiswa ditanya oleh dosen apa yang membuat iklan itu bagus dan bagaimana menarik pelanggan. Pada tahap ini, dosen telah memberikan teks model berupa iklan video yang dapat merangsang mahasiswa untuk melatih keterampilan menyimaknya. Peran intervensionis dosen terungkap saat ia menjamin bahwa siswa mampu memahami desain retorika khas 
yang mereka butuhkan untuk mendorong makna mereka. Dosen berharap mahasiswa mengetahui tujuan, struktur generik, dan ciri kebahasaan teks yang akan diproduksi. Baik dosen dan mahasiswa harus bekerja sama untuk menyelidiki pola struktural dan fitur bahasa untuk memahami teks, meningkatkan kosa kata, akrab dengan komponen. Setelah melihat contoh video iklan dan mendiskusikannya, tahap selanjutnya adalah konstruksi teks bersama. Pada tahap ini, siswa duduk berkelompok untuk membuat draft buku panduan.

Kegiatan ini dilakukan untuk memberikan kelonggaran bagi siswa untuk membagi informasi di antara mereka tentang tempat-tempat wisata yang pernah mereka kunjungi. Menurut dosen dengan mengelompokkan mahasiswa maka akan menyebar mahasiswa dari tingkat bawah ke atas pada masing-masing kelompok untuk saling membantu dalam rangka meningkatkan kemampuan dalam komunikasinya. Hal ini senada dengan Wardhani (2012), bahwa siswa harus giat berkontribusi dengan memberikan "materi pelajaran" untuk naskah. Pada tahap ini, peran pembicara adalah membuktikan bagaimana substansi topik tersebut dapat direncanakan menjadi teks yang koheren. Siswa akan berdiskusi dan berbagi informasi mengenai topik tersebut, seperti yang dikatakan Hyland (2007) bahwa konsep pendukung belajar adalah membantu peserta didik melalui dua pengertian belajar:

1) Kesadaran bersama - gagasan bahwa pelajar yang bekerja bersama belajar lebih efektif daripada individu yang bekerja secara terpisah.
2) Kesadaran yang dipinjam-gagasan bahwa pelajar bekerja dengan orang lain yang berpengetahuan mengembangkan pemahaman yang lebih besar tentang tugas dan ide.

Pada tahap ini siswa sudah bekerja sama dengan temannya dalam satu kelompok untuk membuat draft iklan. Mereka saling berbagi pengetahuan dari data yang mereka miliki dan video yang telah mereka tonton sebelumnya. Mereka saling memberi masukan dan mencari informasi tambahan dari brosur yang mereka miliki dalam membuat draft. Dalam konstruksi bersama teks, dosen harus membimbing mahasiswa untuk membuat teks. Sedangkan dalam temuan penelitian dosen membiarkan mahasiswa bekerja di antara mereka dalam kelompok untuk membuat draft terlebih dahulu. Wardhani (2012) berpendapat bahwa peran pendidik adalah membuktikan bagaimana substansi topik dapat disusun menjadi teks yang jelas. Berdasarkan hasil penelitian, mahasiswa memilih sendiri tempat lokasi untuk diiklankan dan tidak mendapat masukan dari dosen untuk menyusun teks karena dosen yakin mahasiswa sudah paham untuk membuat draft karena sudah melihat sampelnya. video sebelumnya. Pada pertemuan terakhir, siswa mampu membuat draf dengan beberapa revisi yang diperlukan dari usaha mereka sendiri.

Konstruksi independen dari konteks adalah tahap terakhir dalam proses pengomposan. Penulis menemukan bahwa mahasiswa diminta oleh dosen untuk mengembangkan draf revisi mereka menjadi teks iklan tertulis yang lengkap. Dosen membiarkan mahasiswa bekerja sendiri untuk membuat teks berdasarkan draf yang telah direvisi. Dia memberikan bantuan kepada siswa yang menemukan 
kesulitan untuk mengembangkan teks. Ia selalu mengingatkan siswa untuk memperhatikan tata bahasa, kohesi, dan koherensi setiap kalimat untuk membuat paragraf yang baik. Hal ini sejalan dengan (Hyland, 2007) yang mengatakan bahwa pendidik menulis jelas perlu menjadi pendidik bahasa, karena itu adalah bakat untuk melatih pilihan bahasa yang sesuai dalam kebiasaan yang mereka sukai dan menetapkan tema mereka untuk pembaca rinci yang menandai siswa untuk mendanai ide spesialis mereka. Pada tahap terakhir, mahasiswa diinstruksikan oleh dosen untuk menulis teks lengkap dari iklan tertulis secara mandiri. Dosen hanya mengingatkan mahasiswa untuk memperhatikan tata bahasa, kohesi, dan koherensi setiap kalimat agar menjadi paragraf yang baik. Dosen hanya memberikan satu kali kesempatan kepada mahasiswa untuk merevisi draf satu kali, hal ini tidak sejalan dengan Autio (2016) yang mengatakan ketika mahasiswa menulis draf beberapa kali, mengambil untuk belajar dan mengawasi naskah mereka.

Pada umumnya dosen telah menerapkan semua tahapan dalam pendekatan berbasis genre dengan memberikan beberapa kegiatan kepada mahasiswa untuk menghasilkan iklan tertulis. Melalui pendekatan berbasis genre siswa tidak hanya meningkatkan keterampilan menulis mereka, siswa juga dapat melatih keterampilan berbicara mereka ketika mereka berlatih untuk melakukan promosi verbal dan melatih keterampilan mendengarkan ketika mereka melihat contoh video iklan. Sedangkan dalam memproduksi teks iklan tertulis secara utuh, siswa tidak mendapat banyak kesempatan untuk merevisi lebih dari satu kali dan mengedit draft karena keterbatasan waktu pelajaran yang hanya 2 SKS. Dari pembahasan di atas, penulis berasumsi bahwa pendekatan tersebut dapat diterapkan dengan baik jika ada lebih banyak waktu dalam pelajaran mata pelajaran ini. Dapat disimpulkan bahwa dosen telah menerapkan semua tahapan dalam pendekatan berbasis genre yang dapat membantu mahasiswa untuk menghasilkan iklan tertulis. Modifikasi yang dilakukan dosen dalam hal kegiatan di setiap tahapan adalah mendukung mahasiswa menghasilkan iklan tertulis karena kegiatan tersebut mampu merangsang kemampuan mahasiswa berkomunikasi dalam bahasa Inggris, baik lisan maupun lisan. Dengan demikian, penerapan pendekatan ini dapat dianggap berhasil karena siswa mampu menghasilkan iklan tertulis. Dalam penelitian ini terdapat dua jenis pekerjaan siswa, yaitu draft sebelum mereka menulis teks lengkap iklan tertulis dan buku panduan sebagai tugas akhir mata pelajaran bahasa Inggris. Baik draf maupun buku panduan, ada beberapa kekurangan dalam struktur generik. Siswa tidak memberikan judul yang baik seperti memberikan kata-kata yang dapat menarik pelanggan untuk membacanya. Kata-kata itu bisa berupa kata sifat seperti cantik, indah, atau fantastis (Pramujiono, 2011). Sedangkan ilustrasi tempat sudah cukup baik karena siswa sudah memasang beberapa foto objek wisata yang mereka iklankan. Foto-foto tersebut relevan karena sebagian besar adalah pemandangan di sekitar objek. Sedangkan dalam fitur bahasa, siswa masih perlu dibimbing dalam tata bahasa dan kosa kata. Mereka harus lebih mengenal kosakata dalam pariwisata dan bagaimana menggunakan 
kata-kata itu untuk menarik pembaca. Para siswa juga perlu belajar tentang penggunaan kata sifat dan kata kerja. Di antara kata kerja yang paling umum digunakan untuk tujuan ini adalah: "mendapatkan", "memiliki", "melihat", "datang", "pergi", "lihat", "merasa", "seperti". Sebagian besar kata kerja dalam iklan muncul dalam bentuk simple present tense (Saputry, 2016).

Para siswa juga harus belajar lebih banyak tentang mekanisme dalam menulis iklan. Mereka harus tahu betul bagaimana menempatkan koma dan titik yang benar dalam kalimat. Hal ini akan mempengaruhi pembaca untuk lebih mudah dalam memahami pesan yang akan disampaikan. Penempatan koma yang salah dapat mengubah makna dalam kalimat. Melalui fase gabungan gedung dan gedung pemerintahan sendiri, siswa dibimbing langkah demi langkah mulai memilih tempat wisata, informasi penting tempat, membuat draft dan menulis iklan secara individual. Kegiatan ini dilakukan karena menulis merupakan kegiatan yang progresif dan akan dapat membuat siswa membuat tulisan yang baik karena siswa sudah jelas di awal ide sebelum menghasilkan teks. Dan dengan bimbingan dosen, mahasiswa akan mampu mengorganisasikan ide-ide seperti yang dikemukakan oleh Bojuwon \& Ahmed (2013) langkah selanjutnya adalah membuat draft, dan langkah terakhir adalah menyusun teks dan mengedit serta melakukan revisi. Lebih lanjut, Anthony Bunujevac \& Durisic (2017) menyatakan proses penyusunan sebagai tindakan pribadi dapat dilihat secara luas terdiri dari empat tahap utama: menyusun, menyusun, mengubah dan mengubah. Dari hasil kerja siswa, temuan menunjukkan bahwa siswa sudah mampu memproduksi iklan tertulis. Karya siswa sudah memenuhi tujuan iklan yaitu untuk mempromosikan tempat wisata dan menarik pembaca untuk datang dan mengunjungi tempat tersebut. Meskipun mahasiswa mampu menghasilkan iklan tertulis, mereka masih perlu lebih banyak dibimbing agar karyanya lebih sempurna. Tugas siswa disajikan pada tabel berikut.

\section{Tabel 1. Klasifikasi Tugas Siswa}

\begin{tabular}{|c|c|c|}
\hline $\begin{array}{c}\text { Low } \\
\text { (Group 6) }\end{array}$ & $\begin{array}{c}\text { Medium } \\
(\text { Group } 1 \text { \& 4) }\end{array}$ & $\begin{array}{c}\text { High } \\
(\text { Group } 2,3,5 \& 7)\end{array}$ \\
\hline $\begin{array}{l}\text { The target market was not } \\
\text { clearly described, and the } \\
\text { persuasive technique was not } \\
\text { appropriate to the target } \\
\text { market. The creativity in } \\
\text { showing image and slogan } \\
\text { were fewer as well as the } \\
\text { description of the place and } \\
\text { suggestion to visit the place } \\
\text { were less. }\end{array}$ & $\begin{array}{l}\text { The target market was } \\
\text { clearly described and the } \\
\text { persuasive technique was } \\
\text { appropriate to the target } \\
\text { market. The creativity in } \\
\text { showing image and slogan } \\
\text { were good as well as the } \\
\text { description of the place and } \\
\text { suggestion to visit the place } \\
\text { was good. }\end{array}$ & $\begin{array}{l}\text { The target market and } \\
\text { persuasive technique were } \\
\text { excellent as both were } \\
\text { noticeably to the target } \\
\text { market. The creativity in } \\
\text { showing image, slogan and the } \\
\text { description of the place and } \\
\text { suggestion to visit the place } \\
\text { were excellent. }\end{array}$ \\
\hline
\end{tabular}

Secara umum, karya mereka dapat diklasifikasikan sebagai rendah, sedang dan tinggi. Kelompok 6 ini dikategorikan rendah karena target pasar dan teknik persuasif yang buruk, gambar dan slogan yang adil dan teks, ejaan, tata bahasa dan mekanik yang buruk. Kelompok 1 dan 4 
dikategorikan sedang karena target pasar dan teknik persuasif adil, gambar dan slogan adil dan teks, ejaan, tata bahasa dan mekanik adil. Kelompok 2, 3, 5 dan 7 dikategorikan baik karena target pasar dan teknik persuasif baik, gambar dan slogan baik dan teks, ejaan, tata bahasa dan mekanik baik. Dari tabel di atas terdapat 3 kelompok yang tergolong tinggi, 2 kelompok sedang dan 1 kelompok rendah menunjukkan bahwa sebagian besar siswa mampu memproduksi iklan tertulis setelah penerapan pendekatan berbasis genre. Kesimpulannya penerapan metode genre built adalah kepada mahasiswa pariwisata untuk menghasilkan iklan tertulis berhasil

\section{SIMPULAN}

Berdasarkan temuan dan pembahasan penelitian menunjukkan bahwa dosen telah menerapkan semua tahapan dalam pendekatan berbasis genre dengan menggunakan kegiatan yang mendukung mahasiswa untuk menghasilkan iklan tertulis. Dalam membangun pengetahuan teks, dosen menginstruksikan mahasiswa untuk melakukan promosi verbal. Kegiatan ini dilakukan dalam rangka memberikan bagian brainstorming dan merangsang kemampuan siswa dalam berbicara. Setelah siswa melakukan promosi verbal, kegiatan selanjutnya adalah menonton video iklan tentang gadget. Kegiatan ini dilakukan dalam pemodelan tahap selanjutnya. Setelah siswa menonton video, dosen akan memberikan beberapa pertanyaan terkait dengan iklan tersebut, dan siswa akan menganalisis sampel yang representatif dan mengidentifikasi fiturfitur utama serta variasi yang mungkin. Melalui kegiatan ini, dosen ingin memastikan bahwa mahasiswa sudah mengetahui ciri-ciri utama sebuah iklan yang harus dimunculkan dalam promosi, seperti tujuan dan bahasa yang dapat membujuk konsumen. Terakhir, mahasiswa harus menyerahkan hasil karyanya berupa buku panduan sebagai tugas akhir. Karya siswa sudah memenuhi tujuan iklan yaitu untuk mempromosikan tempat wisata dan menarik pembaca untuk datang dan mengunjungi tempat tersebut. Meskipun mahasiswa mampu menghasilkan iklan tertulis, mereka masih perlu lebih banyak dibimbing agar karyanya lebih sempurna.

\section{DAFTAR PUSTAKA}

Ary, D., Jacobs, L.C., Sorensen, C., \& Razavieh, A. (2010). Introduction to Research in Education (8 ed.). Belmont, CA: Wadsworth, Cengage Learning.

Autio, O. (2016). Traditional craft or technology education: Development of students' technical abilities in finnish comprehensive school. International Journal of Research in Education and Science, 2(1), 75-84. https://doi.org/10.21890/ijres.05918

Baker, J. \& Westrup, H. (2012). The English Language Teacher's Handbook. How to teach large classes with few resources London: Continuum.

Bhatia, V. K. (2013). Analysing Genre Language Use in Professional Settings. Oxon: Routledge.

Bojuwon, M., \& Ahmed, S. B. (2013). The Impact of Learning Flexibility, Student Attitude and Internet Quality on E-Learning among (CELPAD) in (IIUM) Malaysia. Nternational Journal of Management Entrepreneurship and Technology (IJMET), 3(1), 1-20.

Bunujevac, M., \& Durisic, M. (2017). Parental Involvement as a Important 
Factor for Successful Education. CEPS Journal, 7(3), 137-153.

Cahyaningsih, R. (2013). Improving Student's Writing Skill Through Genre Based Approach At TenthGrader Of Senior High School Tuban. Universitas Negeri Surabaya.

Cameron, S., \& Myers, S. (2013). Comprehending Functional Text. Alabama: Mark Twain Media, Inc

Deng, L., Chen, Q., \& Zhang, Y. (2014). Developing Chinese EFL Learners' Generic Competence. A Genrebased \& Process Genre Approach New York: Springer.

Flemming, L. (2011). Reading for Result (Eleventh ed.). Boston: Wadsworth Cengage Learning.

Hyland, K. (2007). Genre Pedagogy: Language, literacy and L2 writing instruction. Second Language Writing Vol. 16 No., 148-164.

Manchon, R. (2011). Learning-to-Write and Writing-to-Learn in an Additional Language. Amsterdam: John Benjamins Publishing Company.

Miles, Matthew B., Huberman, M., \& Saldana, J. (2014). Qualitative Data
Analysis: A Methods Sourcebook (3 ed.). Thousand Oaks, CA: SAGE Publications, Inc.

Pramujiono, A. (2011). Representasi Kesantunan Positif-Negatif Brown dan Levinson dalam Wacana Dialog di Televisi. Dipresentasikan dalam Kongres Internasional Masyarakat Linguistik Indonesia, 9-12 Oktober 2011, di Universitas Pendidikan Indonesia.

Saputry, D. (2016). Strategi Kesantunan Positif dan Negatif dalam Bentuk Tuturan Direktif di Lingkungan STKIP Muhammadiyah Pringsewu Lampung. Jurnal Pesona, Volume 2 No. 1, Januari 2016, halaman 149160.

Wardhani, A. K. (2012). Genre Based Approach in The Teaching of Writing To The First Grade Students Of A Senior High School. Universitas Negeri Surabaya. 